REFLECTIONS:

NEUROLOGY AND

THE HUMANITIES

Section Editor

Anne W. McCammon,

MD, FAAN

Nina F. Schor, MD, PhD

Correspondence to

Dr. Schor:

nina_schor@urmc.rochester.edu

\section{The Way It Unfortunately Is}

\section{AWARDS}

"We no longer reward wise," she said.

"We have prizes for smart and clever and big.

We applaud generous, although it rarely holds up when placed on the

'Net worth denominator."'

She left the stage smiling like an emoticon.

Something not quite there, but visible nonetheless.

History and legacy died long ago. Each moment is gone in a flash.

And wisdom, acquired over decades, is seen in a posthumous haze.

\section{PROMOTIONS}

Assistant Professors must demonstrate focus.

Associate Professors must demonstrate breadth.

Full Professors must demonstrate breadth and teach others to demonstrate focus.

Associate Chairs must teach others to demonstrate breadth within their areas of focus.

Chairs must teach others with a broad array of areas of focus to teach others to focus on demonstrating breadth.

The Dean must be a person to whom this all makes sense and seems important.

\section{POMP AND CIRCUMSTANCE}

Academic robes cover denim today.

But neither substance nor form seems to triumph.

Empty and noisy have married and are hoping to raise a cognition-free family. 


\section{Neurology}

\section{The Way It Unfortunately Is}

Nina F. Schor

Neurology 2014;82;e163

DOI 10.1212/WNL.0000000000000414

\section{This information is current as of May 12, 2014}

\section{Updated Information \&} Services

Permissions \& Licensing

Reprints including high resolution figures, can be found at: http://n.neurology.org/content/82/19/e163.full

Information about reproducing this article in parts (figures,tables) or in its entirety can be found online at:

http://www.neurology.org/about/about_the_journal\#permissions

Information about ordering reprints can be found online:

http://n.neurology.org/subscribers/advertise

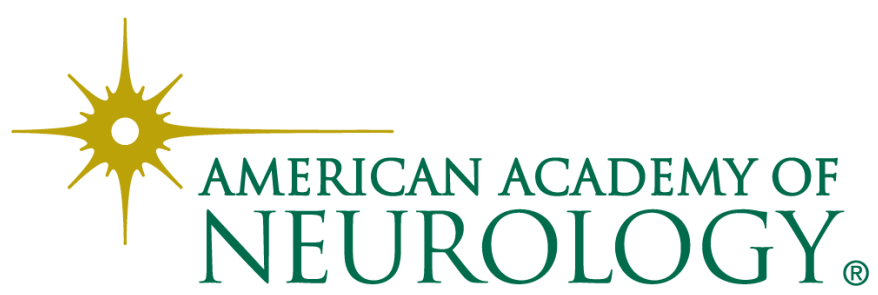

